\title{
6-Carboxymethyl genistein: a novel selective oestrogen receptor modulator (SERM) with unique, differential effects on the vasculature, bone and uterus
}

\author{
D Somjen ${ }^{1}$, Y Amir-Zaltsman, B Gayer, T Kulik, E Knoll' ${ }^{1}$, \\ N Stern ${ }^{1}$, L J W Lu ${ }^{2}$, L Toldo ${ }^{3}$ and F Kohen \\ Department of Biological Regulation, Weizmann Institute of Science, Rehovot, 76100 Israel \\ ${ }^{1}$ Institute of Endocrinology, Tel-Aviv Sourasky Medical Center and the Sackler Faculty of Medicine, Tel-Aviv University, Israel \\ ${ }^{2}$ Department of Preventive Medicine and Community Health, The University of Texas Medical Branch, Galveston, Texas, USA \\ ${ }^{3}$ Department of Bio and Chemoinformatics, Merck KGaA, Darmstadt, Germany \\ (Requests for offprints should be addressed to F Kohen; Email: fortune.kohen@weizmann.ac.il)
}

\begin{abstract}
The novel genistein (G) derivative, 6-carboxymethyl genistein $(\mathrm{CG})$ was evaluated for its biological properties in comparison with G. Both compounds showed oestrogenic activity in vitro and in vivo. On the other hand $\mathrm{G}$ and $\mathrm{CG}$ differed in the following parameters: (i) only CG displayed mixed agonist-antagonist activity for oestrogen receptor (ER) $\alpha$ in transactivation assays and (ii) only CG was capable of attenuating oestrogen $\left(\mathrm{E}_{2}\right)$-induced proliferation in vascular smooth muscle cells and of inhibiting oestrogen-induced creatine kinase (CK) specific activity in rat tissues. On the other hand only $G$ enhanced the stimulatory effect on CK specific activity in the uterus. In comparison to the selective oestrogen receptor modulator (SERM) raloxifene (RAL), CG showed the same selectivity profile as RAL in blocking the CK response to $\mathrm{E}_{2}$ in tissues derived from both immature and ovariectomized
\end{abstract}

female rats. Molecular modelling of CG bound to the ligand binding domain (LBD) of ER $\beta$ predicts that the 6-carboxymethyl group of CG almost fits the binding cavity. On the other hand, molecular modelling of CG bound to the LBD of ER $\alpha$ suggests that the carboxyl group of CG may perturb the end of Helix 11, eliciting a severe backbone change for Leu 525, and consequently induces a conformational change which could position Helix 12 in an antagonist conformation. This model supports the experimental findings that CG can act as a mixed agonist-antagonist when $\mathrm{E}_{2}$ is bound to its receptors. Collectively, our findings suggest that CG can be considered a novel SERM with unique effects on the vasculature, bone and uterus.

Journal of Endocrinology (2002) 173, 415-427

\section{Introduction}

During the last ten years extensive research on genistein (4',5,7-trihydroxy-isoflavone) (Fig. 1) has documented two important observations, one from investigations on the factors responsible for the reduced incidence of breast, prostate and colon cancer in Southeast Asia and the other from the search for pharmacological agents that interfere with growth factor signalling pathways in normal and cancer cells (Barnes et al. 1996). Interest has also focused in recent years on the question whether specific components in the Asian diet may have cancer protective effects (Setchell 2001). Soybean and rice constitute the major diet in East-Asian countries, and soya contains significant amounts of the isoflavones daidzein and genistein (G) which may act as weak oestrogens or as anti-oestrogens. Of these two isoflavones, genistein has been studied a great deal due to its wide spectrum of biological activities, including inhibition of tyrosine phosphorylation of proteins in the signal transduction pathway, inhibition of topoisomerase II, and induction of apoptosis and cell differentiation (Barnes 1997).

The factors determining whether the oestrogenicity or anti-oestrogenicity of isoflavones predominate are quite complex. These factors may be species and/or tissue specific, and may depend on the concentration of the isoflavone, the length of time used and the method of administration (Barnes et al. 2000). Moreover, G shows a greater binding affinity for oestrogen receptor (ER) $\beta$ than for ER a (Kuiper et al. 1998). There is no plausible explanation so far for the distinct ligand binding preference of $\mathrm{G}$ for $\mathrm{ER} \beta$. Additionally, in the three-dimensional structure of the ligand binding domain (LBD) of the ER $\beta-G$ complex the transactivation Helix 12 does not adopt the agonist position, but, instead, lies in a similar orientation to that induced by the selective oestrogen 


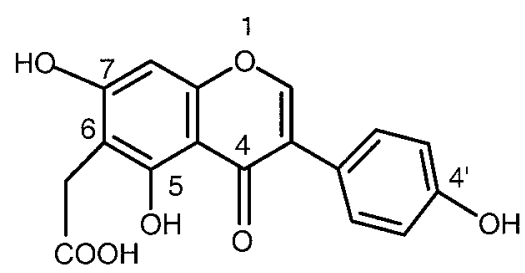

6-Carboxymethyl genistein

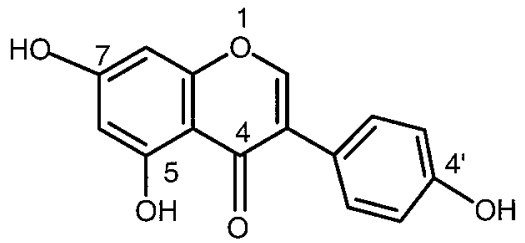

Genistein

Figure 1 Structure of 6-carboxymethyl genistein (CG) and genistein (G).

receptor modulator (SERM) raloxifene (Pike et al. 1999). Such alignment of Helix 12 suggests that $G$ is a partial agonist when bound to ER $\beta$ (Pike et al. 2000, 2001). In view of the fact that $G$ exhibits a wide variety of effects, several analogues of genistein have been synthesized and evaluated for their immunosuppressant and anti-tumour activity (Fiedor et al. 1998). In previous work we have described the synthesis of a novel derivative of $G$ through position 6 of the molecule, 6-carboxymethyl genistein (CG) (Kohen et al. 1999) (Fig. 1), and evaluated its properties as a tyrosine kinase inhibitor in comparison with G. We found that CG did not affect tyrosine kinase activity (Amir-Zaltsman et al. 2000). We have continued our work in evaluating the oestrogenic and antioestrogenic properties of CG. In the present study the in vitro and in vivo oestrogenic and anti-oestrogenic properties of CG in comparison with genistein $(G)$ are described. Our results indicate that CG shows mixed agonistantagonist activity both in vitro and in vivo. In order to explain the observed anti-oestrogenic activity of CG, a computational investigation of the predicted orientation of CG within the LBD of ER $\alpha$ and ER $\beta$ was undertaken. The docked model of CG within the LBD of ER $\beta$ predicts that CG almost fits within the binding pocket. On the other hand, the docked model of CG within the LBD of $\mathrm{ER} \alpha$ predicts that $\mathrm{CG}$ perturbs receptor structure by causing a severe backbone change for Leu 525 in Helix 11. This ligand-induced conformational change in the receptor structure may prevent correct alignment of Helix 12 for recruitment of coactivators (Egner et al. 2001) and cause the observed anti-oestrogenic effect of CG when oestrogen $\left(E_{2}\right)$ is bound to ER $\alpha$. Since $C G$ opposes the effects of oestrogen in rat uterine tissue and shows agonistic effects in bone and vasculature, it can be considered a novel SERM.

\section{Materials and Methods}

\section{Reagents}

All reagents were of analytical grade. Chemicals, tamoxifen, steroids and biotin- $\varepsilon$-aminocaproyl- $\gamma$-butyryl$\mathrm{N}$-succinimide ester were purchased from Sigma ( $\mathrm{St}$
Louis, MO, USA). Isoflavones were purchased from Indofine Chemical Company (Somerville, NJ, USA). Baculovirus-expressed recombinant ER $\alpha$ and ER $\beta$ preparations were from Panvera (Madison, WI, USA). Polyclonal anti-ER $\beta$ antibody was purchased from Santa Cruz (Santa Cruz, CA, USA) and polyclonal anti-ER $\alpha$ antibody was a generous gift from Dr $\mathrm{H}$ Thole (Max-Planck Institute, Germany). [ $\left.{ }^{3} \mathrm{H}\right] 17 \beta$-Oestradiol (85 Ci/mmole) was purchased from New England Nuclear (Boston, MA, USA). Streptavidin-coated plates were from Wallac (Turku, Finland). Raloxifene was extracted into ethanol from commercially available tablets (Evista).

\section{Synthesis of carboxy derivatives of isoflavones}

6-Carboxymethyl genistein (CG) (see Fig. 1 for the structure) was prepared as described previously (Kohen et al. 1999).

\section{Biotinylation of antibodies}

Anti-ER antibodies were biotinylated with biotin- $\varepsilon$ aminocaproyl- $\boldsymbol{\gamma}$-butyryl-N-succinimide ester as previously described (Strasburger \& Kohen 1990).

\section{Receptor-binding assays}

Recombinant ER $\alpha$ or $E R \beta$ proteins $(12 \mathrm{pmol} / \mathrm{ml})$ in $10 \mu \mathrm{l}$ binding buffer (10 mM Tris, $\mathrm{pH} 7 \cdot 5$, containing $10 \%$ glycerol, $2 \mathrm{mM}$ dithiothreitol (DTT), and $1 \mathrm{mg} / \mathrm{ml} \mathrm{BSA}$ ) were incubated in streptavidin-coated microtitre plates for $30 \mathrm{~min}$ at room temperature, in the absence or presence of serial dilutions of oestrogen in $50 \mu \mathrm{l}$ binding buffer or test compounds. Subsequently, $\left[{ }^{3} \mathrm{H}\right] \mathrm{E}_{2}(3 \mathrm{nM})$ in $50 \mu$ binding buffer was added to each well, and the mixtures were incubated overnight at $4{ }^{\circ} \mathrm{C}$. Biotinylated anti-ER antibody $(\alpha$ or $\beta)(100 \mathrm{ng} /$ well in $100 \mu \mathrm{l}$ binding buffer $)$ was added to each well, and the reaction mixtures were incubated with shaking for $2.5 \mathrm{~h}$ at room temperature. The reaction mixtures were then decanted, and each well was washed once with binding buffer. Dilute sodium hydroxide $(0.4 \mathrm{mM}, 300 \mu \mathrm{l})$ was added to each well. After shaking for $20 \mathrm{~min}$, an aliquot $(200 \mu \mathrm{l})$ was removed from 
each well and added to a vial containing scintillation fluid. The vials were then counted for radioactivity in a beta scintillation counter.

\section{Transfection and luciferase assay}

MCF-7 human breast cancer (National Cancer Institute, Bethesda, MD, USA) or human 293 embryonal kidney cells (American Type Tissue Collection (ATTC), Rockville, MD, USA) were plated in 24-well plates at a density of 50000 cells/well in complete medium consisting of RPMI-1640 or DMEM containing phenol red supplemented with 10\% fetal calf serum (FCS) (Biological Industries, Beth Haemek, Israel), 2\% L-glutamine and antibiotics. Cells were incubated for $72 \mathrm{~h}$ at $37^{\circ} \mathrm{C}$ in a humidified atmosphere of $8 \% \mathrm{CO}_{2}$-air. Afterwards, the medium of each well was aspirated, and each well received $0.5 \mathrm{ml}$ phenol red-free RPMI-1640 or DMEM without FCS and antibiotics. The MCF-7 cells were then transfected following the Geneporter procedure (Gene Therapy Systems, San Diego, CA, USA) with three plasmids: (a) 3 xERE-TATA-Luc reporter plasmid (360 ng/well, from Dr Bart van der Burg, Utrecht, The Netherlands); (b) pEGFP-C1 (120 ng/well, from CLONETECHniques, Palo Alto, CA, USA) for visualization of transfection and (c) Renilla phRL (48 ng/well, from Promega, Madison, WI, USA) for normalizing the luciferase activity of the reporter plasmid in each well. The 293 cells were transfected with the same plasmids as the MCF-7 cells and a fourth plasmid containing the human ER $\alpha$ (pRST7-ER $\alpha$ from Dr D McDonnell, Durham, $\mathrm{NC}$, USA; $8 \mathrm{ng}$ /well) or ER $\beta$ (pRST7ER $\beta$ long form encoding 530 amino acids, from Dr D McDonnell; $8 \mathrm{ng} /$ well) was introduced. The cells were first incubated with $25 \mu \mathrm{l}$ DNA and liposome solution for $3 \mathrm{~h}$ at $37^{\circ} \mathrm{C}$ and subsequently, $0.5 \mathrm{ml}$ phenol red-free RPMI-1640 or DMEM medium containing 20\% charcoal-treated FCS and antibiotics were added to each well. After an overnight incubation at $37^{\circ} \mathrm{C}$, the transfected cells were washed twice with PBS and treated with various test chemicals in complete medium without phenol red and supplemented with 10\% charcoal-treated fetal calf serum. After an overnight incubation, treated cells were rinsed with PBS. Firefly and Renilla luciferase activity were determined using the Dual Luciferase Reporter assay system (Stop and Glow from Promega) and a luminometer (M2010A) from Lumac (Landgraaf, Holland).

\section{Cell cultures}

Human umbilical artery vascular smooth muscle cells (VSMC) Human umbilical artery VSMC were prepared as previously described with minor modifications (Somjen et al. 1998). In brief, umbilical cords were collected shortly after delivery. The umbilical arteries were cleaned of blood and adventitia and then cut into 1-3 mm slices. The segments were kept in culture in Medium 199 containing 20\% FCS, glutamine and antibiotics. Cell migration was detectable within 5-7 days. Cells were fed twice a week and, upon confluence, trypsinized and transferred to 24-well dishes. Cells were used only at passages 1-3 when expression of smooth muscle actin was clearly demonstrable.

Endothelial cells (E304) E304 cells, an endothelial cell line derived from a human umbilical vein, were purchased from ATCC, and grown in Medium 199 containing 10\% FCS, glutamine and antibiotics.

\section{Assessment of DNA synthesis}

Cells were grown until subconfluence and then treated with various hormones or agents as indicated. Twenty-two hours later, $\left[{ }^{3} \mathrm{H}\right]$ thymidine was added for two hours. Cells were then treated with $10 \%$ ice-cold trichloroacetic acid (TCA) for $5 \mathrm{~min}$ and washed twice with 5\% TCA and then with cold ethanol. The TCA extracts were combined and dissolved in $0.3 \mathrm{ml} 0.3 \mathrm{M} \mathrm{NaOH}$, samples were taken and aliquots were taken for measurement of $\left[{ }^{3} \mathrm{H}\right]$ thymidine incorporation into DNA as previously described (Somjen et al. 1998).

\section{Animals}

Immature, 25-day-old, female Wistar rats were used at the age of 25 days. Ovariectomy was performed at the age of 25 days, and the various treatments were carried out 2 weeks after surgery. The colony was housed in airconditioned quarters with light from 0500 to $1900 \mathrm{~h}$ and had access to Purina Laboratory Chow and water. All experiments were carried out according to the regulations of the committee of the experimental animals of the Weizmann Institute of Science.

\section{Creatine kinase extraction and assay}

In vitro Cells were treated for $24 \mathrm{~h}$ with the various hormones and agents as specified. Cells were then scraped off the culture dishes and homogenized by freezing and thawing three times in an extraction buffer as previously described (Somjen et al. 2000). Supernatant extracts were obtained by centrifugation of homogenates at $14000 \boldsymbol{g}$ for 5 min at $4{ }^{\circ} \mathrm{C}$ in an Eppendorf microcentrifuge. Creatine kinase (CK) was determined by a coupled spectrophotometric assay (Sigma) as described previously (Somjen et al. 2000). Protein was determined by Coomassie blue dye binding using bovine serum albumin as the standard.

In vivo Changes in $\mathrm{CK}$ specific activity in the epiphyseal cartilage, diaphyseal bone, uterus, pituitary, aorta, and left ventricle of the heart, induced by the short-term treatment with $E_{2}$, $G$ and $C G$ were studied in 25-day-old immature 
or one-month-old ovariectomized female rats, two weeks after surgery (five animals per group using the doses indicated for each experiment). Rats injected intraperitoneally (i.p.) with $0.05 \%$ ethanol in PBS served as controls. The $\mathrm{E}_{2}$ dose used for each rat was $5 \mu \mathrm{g}$, since this dose is optimal for bone tissue. The rats were killed by decapitation $24 \mathrm{~h}$ after i.p. injection. The various organs were removed and stored at $-20{ }^{\circ} \mathrm{C}$ until processed for CK activity.

\section{Statistical analysis}

The significance of differences between the mean values obtained from experimental and controls rats was evaluated by the unpaired two-tailed Student's $t$-test and by analysis of variance (ANOVA).

\section{Computer modeling of 6-carboxymethyl genistein bound to $E R \beta$}

A structural model of CG bound to the ligand binding domain (LBD) of human ER $\beta$ was built manually by altering the G structure as observed in 1 QKM (Pike et al. 1999) using SYBYL modules (Tripos Inc., St Louis, MO, USA). A carboxyl methyl group was added to position 6 of the isoflavone ring and oriented optimally in order to minimize unfavourable interactions. Energy minimization and docking were subsequently performed with the SYBYL modules, using default parameters. This model is named CG-ER $\beta$-(alpha face) to indicate that the ring hydroxyl (position 5) and keto group (position 4) of CG (Fig. 1) point towards the alpha face (Pike et al. 2001) of the binding cavity.

\section{Computer modeling of 6-carboxymethyl genistein bound to $E R a$}

The model of CG bound to the LBD of human ER $\alpha$ was generated using SYBYL modules by superimposing the protein backbone of the CG-ER $\beta$ complex with that of 1 ERE (Brzozowski et al. 1997), followed by manual refinement of the CG's carboxyl orientation, energy minimization and docking. In this model the oxygen atom at position 4 of CG is directed towards the alpha face of the binding cavity and is referred to as CG-ER alpha face. Using this model CG was then rotated 180 degrees over a diagonal going through the phenolic hydroxyl group at position $4^{\prime}$ and the hydroxyl group at position 7 . The model was then energy minimized and docked as above. This is the model of CG-ER $\alpha$ through the beta face. Ligand protein contact (LPC) was used to generate final ligand-protein contact data (Sobolev et al. 1999). Connolly surfaces, computed by SYBYL, were chosen for visualising relevant LPC areas of the protein.
Table 1 Relative binding affinity (RBA) of genistein analogues for $E R \alpha$ and ER $\beta$. The RBA for each competitor was calculated as the ratio of concentrations of oestrogen $\left(E_{2}\right)$ and competitor required to reduce $\left[{ }^{3} \mathrm{H}\right]$ oestradiol by $50 \%$ (= ratio of $I C_{50}$ values). The RBA value for $E_{2}$ was arbitrarily set at 100 . The $I C_{50}$ value for $E_{2}$ was $0 \cdot 8 \mathrm{nM}$ for $\mathrm{ER} \alpha$ and $1 \mathrm{nM}$ for $\mathrm{ER} \beta$

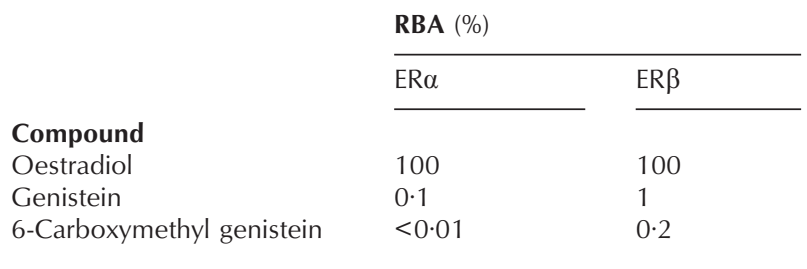

\section{Results}

Oestrogen receptor binding studies

In binding assays, carried out as described in the Materials and Methods section, $G$ and CG show a relative binding affinity (RBA) to $E R \beta$ of 1 and $0 \cdot 2 \%$ respectively. On the other hand $G$ shows an RBA of $0 \cdot 1 \%$ to ER $\alpha$ while $C G$ does not significantly inhibit the binding of $\left[{ }^{3} \mathrm{H}\right]$ oestradiol to $\operatorname{ER} \alpha$ (Table 1).

\section{Transcriptional activity of genistein analogues}

The transactivation activity of G and CG was measured after incubation of transfected culture cells with $G$ analogues $(1 \mu \mathrm{M})$ in the absence or presence of $\mathrm{E}_{2}(1 \mathrm{nM}$ in MCF-7 and 293 cells transfected with ER $\alpha$ and $10 \mathrm{nM}$ in 293 cells transfected with ER $\beta$ ). G showed only strong agonistic activity in MCF-7 (Fig. 2A) and 293 cells transfected with both subtypes (Fig. $2 \mathrm{~B}$ and $\mathrm{C}$ ), and no inhibitory activity in the presence of $E_{2}$. On the other hand, the agonistic activity of CG was moderate in MCF-7 and 293 cells transfected with ER $\alpha$ and strong in 293 cells transfected with ER $\beta$. Moreover, CG in the presence of $E_{2}$ in MCF-7 and 293 cells transfected with ER $\alpha$ displayed a mixed agonist-antagonist activity for ER $\alpha$ (Fig. 2A, B), and no antagonism could be detected in 293 cells transfected with ER $\beta$ (Fig. 2C). Under the same experimental conditions, tamoxifen $(1 \mu \mathrm{M})$ showed antagonist activity only in MCF-7 and 293 cells transfected with ER $\alpha$ (Fig. 2A,B) and no antagonism in cells transfected with ER $\beta$ (Fig. 2C) could be detected.

Effects of genistein analogues on $\left.\beta^{3} H\right]$ thymidine incorporation and $C K$ specific activity in vitro

Human VSMC Both $\mathrm{E}_{2}(0.3 \mathrm{nmol} / 1$ to $30 \mathrm{nmol} / \mathrm{l})$ and G $(0 \cdot 3 \mathrm{nmol} / 1$ to $3000 \mathrm{nmol} / \mathrm{l})$ had a biphasic effect on DNA synthesis. At a low concentration of $\mathrm{E}_{2}(0 \cdot 3 \mathrm{nmol} / \mathrm{l})$, $\left[{ }^{3} \mathrm{H}\right]$ thymidine incorporation was stimulated, whereas higher concentrations of $\mathrm{E}_{2}(>30 \mathrm{nmol} / \mathrm{l})$ led to inhibition 

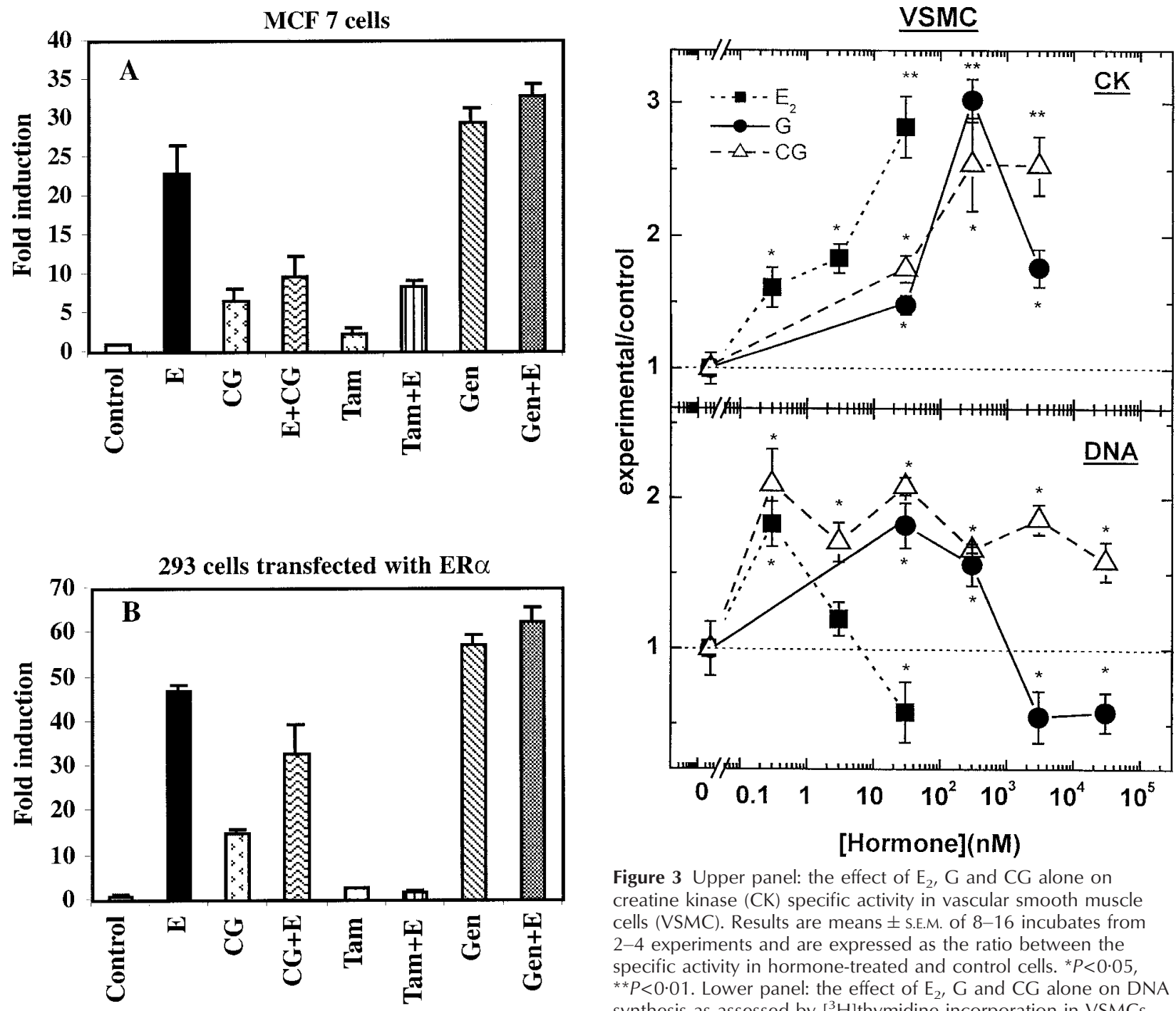

Figure 3 Upper panel: the effect of $E_{2}, G$ and $C G$ alone on creatine kinase (CK) specific activity in vascular smooth muscle cells (VSMC). Results are means \pm S.E.M. of 8-16 incubates from 2-4 experiments and are expressed as the ratio between the specific activity in hormone-treated and control cells. ${ }^{*} P<0 \cdot 05$, ${ }^{*} P<0 \cdot 01$. Lower panel: the effect of $E_{2}, G$ and CG alone on DNA synthesis as assessed by $\left[{ }^{3} \mathrm{H}\right]$ thymidine incorporation in VSMCs. Results are means \pm S.E.M. of $8-16$ incubates from 2-4 experiments and are expressed as the ratio between $\left[{ }^{3} \mathrm{H}\right]$ thymidine incorporation in hormone-treated and control cells. The dashed lines represent the control basal activity. ${ }^{*} P<0 \cdot 05$.

293 cells transfected with $\mathbf{E R} \beta$

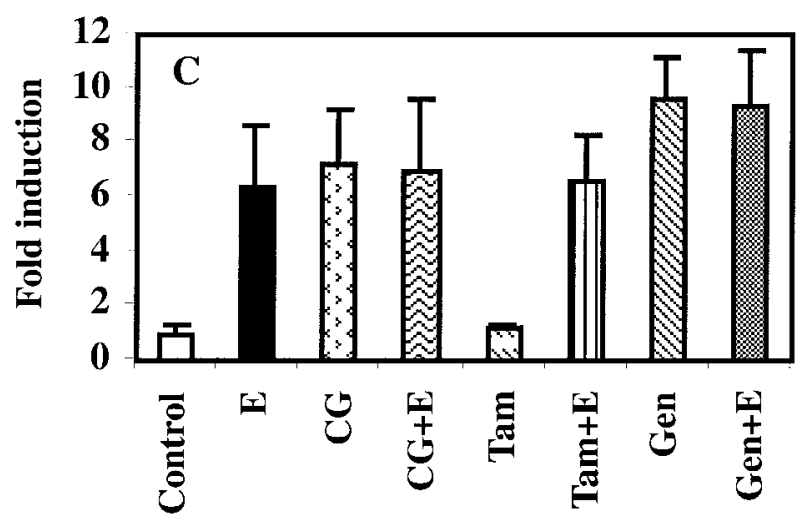

Figure 2 (left) Transcriptional activation of $E R \alpha$ and $E R \beta$ with oestrogen $\left(\mathrm{E}_{2}\right), \mathrm{G}(\mathrm{Gen})$ or CG. MCF-7 human breast cancer cells were transfected with three plasmids consisting of 3xERE-TATA-Luc reporter, green protein (pEGFP-C1) and Renilla luciferase. 293 kidney embryonic cells were transfected with the same three plasmids as the MCF-7 cells and in addition a fourth plasmid containing the cDNA for human ER $\alpha$ or ER $\beta$ was introduced. The cells were then treated with $E_{2}\left(10^{-9} \mathrm{M}\right.$ (MCF-7 and 293 cells transfected with ER $\alpha$ ) or $10^{-8} \mathrm{M}$ (293 cells transfected with ER $\beta)), G(1 \mu \mathrm{M}), \mathrm{CG}(1 \mu \mathrm{M})$, tamoxifen (Tam, $1 \mu \mathrm{M})$, or combinations of $E_{2}+G, E_{2}+C G, E_{2}+$ Tam. Firefly luciferase activity was performed $24 \mathrm{~h}$ later. Luciferase activity was standardized to the internal co-transfected Renilla activity and expressed as the ratio of induced activity to the activity in the absence of ligand. Each data point represents the mean \pm S.D. of triplicates of 3 different experiments. 
Table 2 Concentration dependent interactions of genistein analogues with $E_{2}$ or raloxifene (RAL) in terms of DNA synthesis or CK specific activity in human vascular smooth muscle cells. Results are means \pm S.E.M. of 8-16 incubates from 2-4 experiments and are expressed as the ratio between $\left[{ }^{3} \mathrm{H}\right]$ thymidine incorporation in hormone-treated and control cells or as the ratio between the specific activity of CK in hormone-treated and control cells

\begin{tabular}{|c|c|c|}
\hline & DNA synthesis & $\begin{array}{l}\text { CK specific } \\
\text { activity }\end{array}$ \\
\hline \multicolumn{3}{|l|}{ Compound } \\
\hline \multicolumn{3}{|l|}{ Low dose } \\
\hline $\mathrm{E}_{2}(0 \cdot 3 \mathrm{nM})$ & $1 \cdot 76 \pm 0 \cdot 17^{* *}$ & $1 \cdot 52 \pm 0.08^{*}$ \\
\hline Ral (30 nM) & $1 \cdot 77 \pm 0 \cdot 11^{* *}$ & $1 \cdot 57 \pm 0 \cdot 17^{*}$ \\
\hline $\operatorname{Ral}(30 \mathrm{nM})+\mathrm{E}_{2}(0 \cdot 3 \mathrm{nM})$ & $1 \cdot 73 \pm 0 \cdot 17^{* *}$ & $0 \cdot 90 \pm 0 \cdot 11$ \\
\hline $\mathrm{G}(30 \mathrm{nM})$ & $1 \cdot 78 \pm 0 \cdot 13^{* *}$ & $3 \cdot 02 \pm 0 \cdot 16^{* *}$ \\
\hline $\mathrm{G}(30 \mathrm{nM})+\mathrm{Ral}(30 \mathrm{nM})$ & $1 \cdot 93 \pm 0 \cdot 15^{\star *}$ & $1 \cdot 28 \pm 0 \cdot 15$ \\
\hline$G(30 n M)+E_{2}(0 \cdot 3 n M)$ & $2 \cdot 82 \pm 0 \cdot 18^{\star * *}$ & $3 \cdot 59 \pm 0 \cdot 11^{* * *}$ \\
\hline CG $(30 \mathrm{nM})$ & $1 \cdot 90 \pm 0 \cdot 1^{* *}$ & $1 \cdot 85 \pm 0 \cdot 2^{*}$ \\
\hline CG (30 nM)+Ral (30 nM) & $1 \cdot 62 \pm 0 \cdot 19^{*}$ & $1 \cdot 08 \pm 0 \cdot 12$ \\
\hline CG $(30 \mathrm{nM})+\mathrm{E}_{2}(0 \cdot 3 \mathrm{nM})$ & $1 \cdot 02 \pm 0 \cdot 18$ & $1 \cdot 12 \pm 0 \cdot 18$ \\
\hline \multicolumn{3}{|l|}{ High dose } \\
\hline $\mathrm{E}_{2}(30 \mathrm{nM})$ & $0 \cdot 65 \pm 0 \cdot 16^{*}$ & $2 \cdot 49 \pm 0 \cdot 15^{\star *}$ \\
\hline Ral $(3 \mu \mathrm{M})$ & $0 \cdot 47 \pm 0 \cdot 11^{* *}$ & $1 \cdot 69 \pm 0 \cdot 13^{* *}$ \\
\hline Ral $(3 \mu M)+E_{2}(30 n M)$ & $0 \cdot 56 \pm 0 \cdot 16^{\star}$ & $1 \cdot 46 \pm 0 \cdot 28^{*}$ \\
\hline $\mathrm{G}(3 \mu \mathrm{M})$ & $0 \cdot 59 \pm 0 \cdot 11^{* *}$ & $3 \cdot 43 \pm 0 \cdot 22^{* * *}$ \\
\hline $\mathrm{G}(3 \mu \mathrm{M})+\operatorname{Ral}(3 \mu \mathrm{M})$ & $0 \cdot 53 \pm 0 \cdot 12^{*}$ & $0 \cdot 91 \pm 0 \cdot 12$ \\
\hline$G(3 \mu M)+E_{2}(30 n M)$ & $0 \cdot 48 \pm 0 \cdot 13^{* *}$ & $5 \cdot 23 \pm 0 \cdot 31^{* * *}$ \\
\hline CG $(3 \mu \mathrm{M})$ & $1 \cdot 76 \pm 0 \cdot 11^{\star *}$ & $2 \cdot 54 \pm 0 \cdot 35^{* *}$ \\
\hline CG $(3 \mu \mathrm{M})+\operatorname{Ral}(3 \mu \mathrm{M})$ & $0 \cdot 86 \pm 0 \cdot 31$ & $1 \cdot 28 \pm 0 \cdot 18$ \\
\hline$C G(3 \mu M)+E_{2}(30 n M)$ & $0 \cdot 96 \pm 0 \cdot 12$ & $1 \cdot 18 \pm 0 \cdot 25$ \\
\hline
\end{tabular}

Low dose: cells were treated with either G (30 nM) or CG (30nM) alone or in the presence of RAL (30 nM) or $E_{2}(0 \cdot 3 \mathrm{nM})$ and assayed for $\left[{ }^{3} \mathrm{H}\right]$ thymidine incorporation and $\mathrm{CK}$ specific activity. High dose: cells were treated with either $\mathrm{G}(3 \mu \mathrm{M})$ or CG $(3 \mu \mathrm{M})$ alone or in the presence of RAL $(3 \mu \mathrm{M})$ or $\mathrm{E}_{2}(30 \mathrm{nM})$ and assayed for $\left[{ }^{3} \mathrm{H}\right]$ thymidine incorporation and CK specific activity. ${ }^{*} P<0 \cdot 05,{ }^{* *} P<0 \cdot 01,{ }^{* * *} P<0 \cdot 005$.

of DNA synthesis (Fig. 3, lower panel). Similar doserelated effects were seen with $G$, i.e. stimulation with a low concentration $(30 \mathrm{nmol} / \mathrm{l})$ and inhibition with high concentrations ( $>3 \mu \mathrm{mol} / \mathrm{l}$ ) (Fig. 3, lower panel). On the other hand, CG had a monophasic stimulatory effect on DNA synthesis and exerted no inhibitory effect at high concentrations (Fig. 3, lower panel). Additionally, cells were more sensitive to CG than to $G$ (two orders of magnitude). Interestingly, both compounds at $30 \mathrm{nmol} / 1$ increased significantly the CK specific activity in these cells, but this was maximal at $300 \mathrm{nmol} / \mathrm{l}$ (Fig. 3 upper panel).

In order to study further the anti-oestrogenic activities of CG in VSMCs the dose-dependent interactions of $\mathrm{G}$ or CG with $\mathrm{E}_{2}$ or the SERM raloxifene (RAL) were investigated. The combination of $\mathrm{G}$ at low dose $(30 \mathrm{nM})$ with $\mathrm{E}_{2}(0 \cdot 3 \mathrm{nM})$ augmented the response to $\mathrm{E}_{2}$ by VSMC in terms of DNA synthesis and CK specific activity (Table

\section{E304}

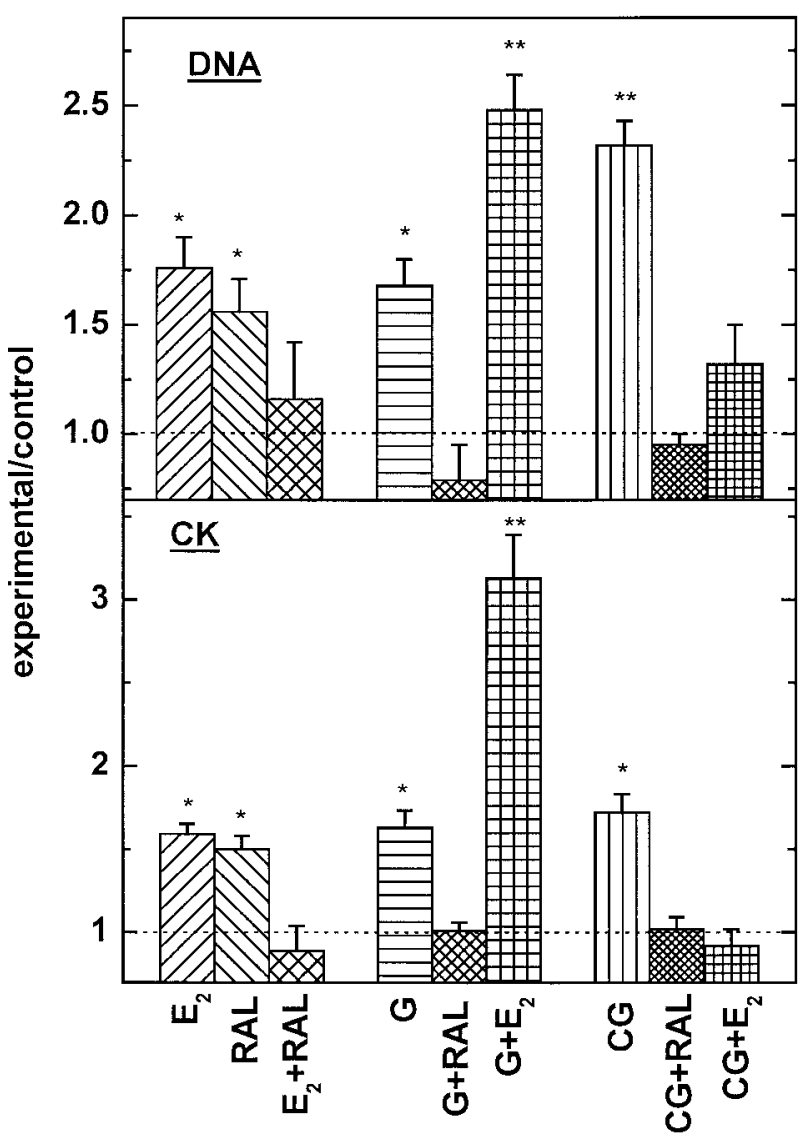

Figure 4 The effect of $E_{2}(30 \mathrm{nM}), \mathrm{G}(3 \mu \mathrm{M}), \mathrm{CG}(300 \mathrm{nM})$ or raloxifene (RAL $3 \mu \mathrm{M})$ alone or in the presence of either raloxifene $(\mathrm{RAL} 3 \mu \mathrm{M})$ or $\mathrm{E}_{2}(30 \mathrm{nM})$ on DNA synthesis (upper panel) and on CK (lower panel) in E304 cells. Results are means \pm S.E.M. of 8-16 incubates from 2-4 experiments and are expressed as the ratio between $\left[{ }^{3} \mathrm{H}\right]$ thymidine incorporation (DNA) or the specific activity of $\mathrm{CK}$ in hormone-treated and control cells. ${ }^{*} P<0 \cdot 05$, ${ }^{* *} P<0 \cdot 01$. The control basal activity is shown as a dashed line.

2). The combination of CG $(30 \mathrm{nM})$ with $\mathrm{E}_{2}(0 \cdot 3 \mathrm{nM})$ caused an inhibition of both cell proliferation and stimulation of CK specific activity (Table 2 ). On the other hand, combination of $\mathrm{G}$ at high dose $(3 \mu \mathrm{M})$ with $\mathrm{E}_{2}(30 \mathrm{nM})$ caused slightly increased suppression of cell proliferation and an increased stimulation in CK specific activity. The combination of $\mathrm{CG}$ at low or high dose with $\mathrm{E}_{2}$ had an inhibitory effect on CK specific activity (Table 2).

In the next set of experiments the inhibitory effects of the SERM RAL were studied. RAL inhibited CK induction by either high or low doses of $E_{2}, G$ and $C G$ (Table 2). On the other hand, DNA synthesis induced by $E_{2}$ or $G$ at high or low dose was unaffected by RAL (Table 2). Only CG-induced DNA synthesis at high doses was blocked by RAL (Table 2). 


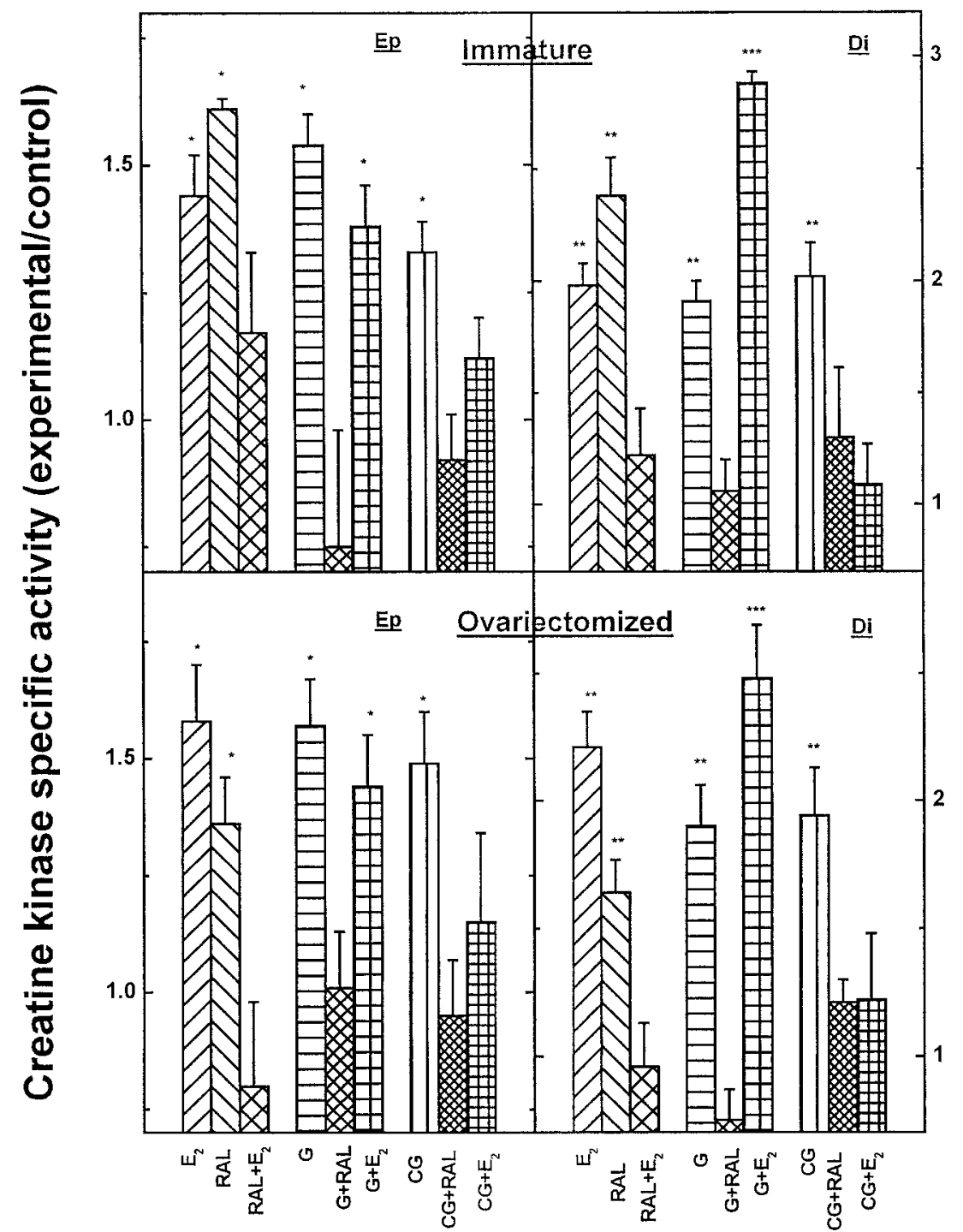

Figure 5 The effect of $E_{2}(5 \mu \mathrm{g}), \mathrm{G}(0.5 \mathrm{mg}), \mathrm{CG}(50 \mu \mathrm{g})$ and $\mathrm{RAL}(0.5 \mathrm{mg})$ alone or in the presence of RAL $(0.5 \mathrm{mg})$ or $\mathrm{E}_{2}(5 \mu \mathrm{g})$ on $\mathrm{CK}$ in epiphyseal cartilage (Ep) and diaphyseal bone (Di) in immature (upper panel) or ovariectomized (lower panel) female rats. Results are means \pm S.E.M. of 5-15 assays from 2-3 experiments and are expressed as the ratio between the specific activity of $\mathrm{CK}$ in hormone-treated and control animals. ${ }^{*} P<0 \cdot 05$, ${ }^{* *} P<0 \cdot 01,{ }^{* * *} P<0 \cdot 001$.

Endothelial cells (E304) $\quad E_{2}(0 \cdot 3 \mathrm{nmol} / \mathrm{l}), \mathrm{G}(30 \mathrm{nmol} /$ 1) and CG (30 nmol/l) increased both DNA synthesis (Fig. 4, upper panel) and CK specific activity (Fig. 4, lower panel) in these cells. Combination of $E_{2}$ with $G$ further augmented the response to $\mathrm{E}_{2}$ with respect to DNA synthesis and CK specific activity. On the other hand CG in the presence of $\mathrm{E}_{2}$ inhibited both cell proliferation and CK activity. Raloxifene (RAL) inhibited both DNA and $\mathrm{CK}$ induced by $\mathrm{E}_{2}$, G or CG (Fig. 4).
Stimulation of the CK specific activity by genistein analogues in vivo

Immature and ovariectomized female rats were injected with $\mathrm{E}_{2}(5 \mu \mathrm{g} / \mathrm{rat}), \mathrm{G}(0.5 \mathrm{mg} / \mathrm{rat})$, CG $(100 \mu \mathrm{g} / \mathrm{rat})$ or $\operatorname{RAL}(0.5 \mathrm{mg} / \mathrm{rat})$ or with the combination of $\mathrm{E}_{2}+\mathrm{G}$, $\mathrm{E}_{2}+\mathrm{CG}, \mathrm{E}_{2}+\mathrm{RAL}, \mathrm{G}+\mathrm{RAL}$ or CG+RAL. $\mathrm{E}_{2}$ and $\mathrm{G}$ stimulated the CK specific activity in all the rat tissues (epiphyseal cartilage and diaphyseal bone (Fig. 5, upper and lower panel), pituitary and uterus (Fig. 6, upper and 


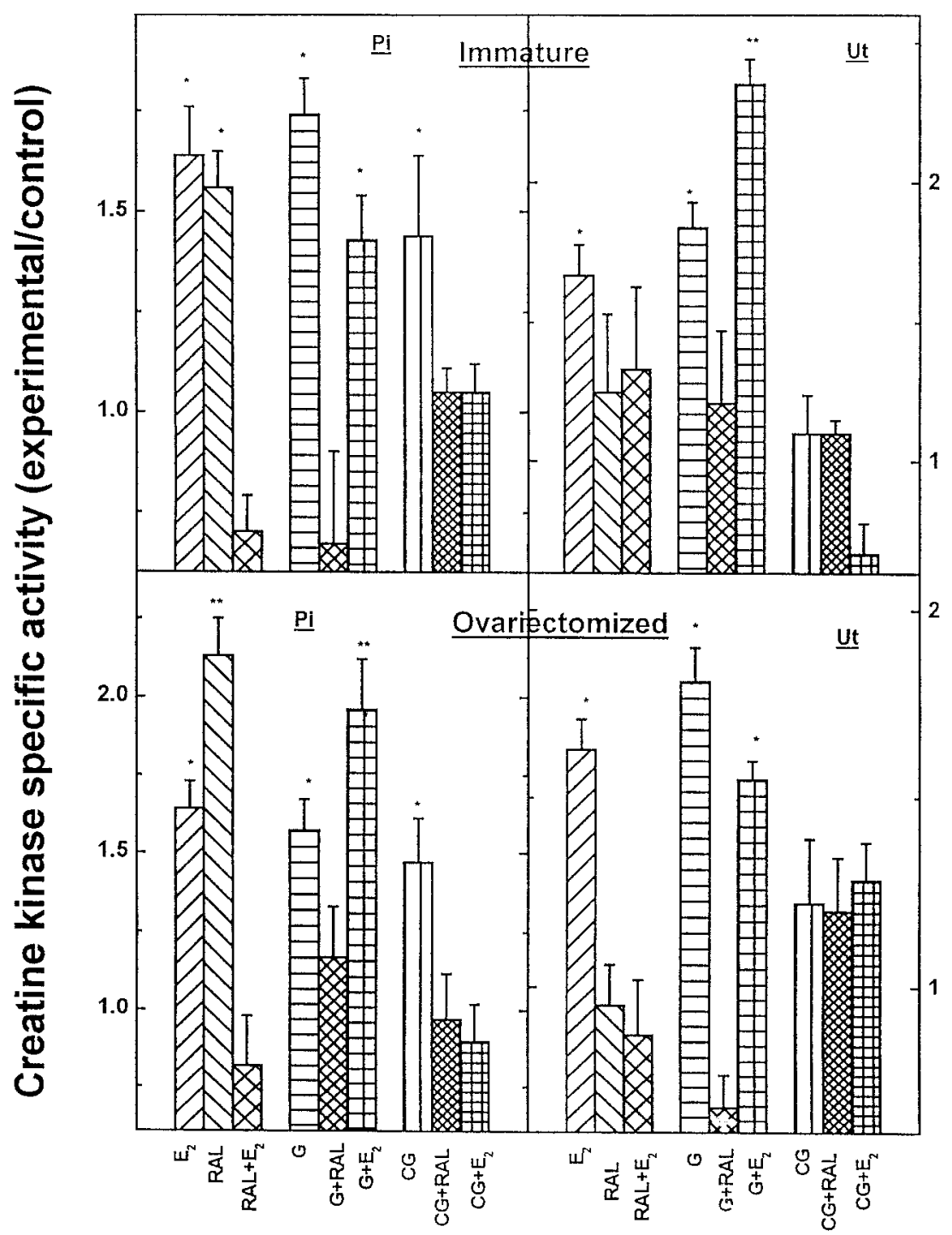

Figure 6 The effect of $\mathrm{E}_{2}(5 \mu \mathrm{g}), \mathrm{G}(0.5 \mathrm{mg}), \mathrm{CG}(50 \mu \mathrm{g})$ and $\mathrm{RAL}(0.5 \mathrm{mg})$ alone or in the presence of RAL $(0.5 \mathrm{mg})$ or $\mathrm{E}_{2}(5 \mu \mathrm{g})$ on CK specific activity in pituitary (Pi) and uterus (Ut) in immature (upper panel) or ovariectomized (lower panel) female rats. Results are means \pm S.E.M. of 5-15 assays from 2-3 experiments and are expressed as the ratio between the specific activity of CK in hormone-treated and control animals. ${ }^{*} P<0 \cdot 05$, ${ }^{* *} P<0 \cdot 01$.

lower panel), left ventricle of the heart and aorta (Fig. 7, upper and lower panel)) that were tested, while CG increased the CK specific activity in all the rat tissues with the exception of the uterus (Fig. 6). On the other hand, RAL was stimulatory in the diaphysis, epiphysis, pituitary, aorta and left ventricle but not in the uterus. The stimulatory response of $\mathrm{E}_{2}$ to $\mathrm{CK}$ specific activity was inhibited in all the tissues when rats were treated with a combination of $\mathrm{E}_{2}$ plus $\mathrm{CG}$ or $\mathrm{E}_{2}$ plus RAL (Figs 5-7), suggesting that $\mathrm{CG}$ acts like a SERM in these tissues. Moreover, the combination of $E_{2}$ plus $G$ augmented the
CK response to $\mathrm{E}_{2}$ in the aorta and pituitary and not in the remaining rat tissues. When rats were treated with $G$ or CG plus RAL, the CK response to G or CG was blocked in all the tissues tested (Figs 5-7).

\section{Computer model of the 6-carboxymethyl genistein bound to $E R \beta$}

The docked model of the LBD-ER $\beta-C G$ complex is shown in Fig. 8. In this model the phenolic group at position 5 and the keto group at position 4 of CG point 
towards the alpha face of the binding cavity. The 6-carboxymethyl group in CG is bumping against the floor of the cavity made by Ile 373 and Ile 376. CG almost fits the binding cavity and can adapt slightly in the binding pocket since the small size of Ile residues do not decrease the volume and polarity of the binding pocket.

\section{Computer model of 6-carboxymethyl genistein bound to ERa}

The docked model of the LBD-ER $\alpha-C G$ complex and the receptor bound conformation observed for 4-OH tamoxifen pointing towards the beta face of the binding cavity are illustrated in Fig. 9. The docked geometries for $\mathrm{CG}$ and 4-OH tamoxifen suggest that the same amino acid residues (Arg 394 and Glu 353) in the LBD of ER $\alpha$ are involved in anchoring CG through the phenolic group at position $4^{\prime}$ and tamoxifen through the $4-\mathrm{OH}$ group (Pike et al. 2000). On the other hand, the two structures differ with respect to the orientation of side chains. In 4-OH tamoxifen the side chain exits through Helix 3 and 11 whereas in CG the 6-carboxymethyl group perturbs the end of Helix 11. This perturbation may lead to a severe backbone change for Leu 525 which may result in an antagonist conformation of Helix 12 (Fig. 9). The model shown in Fig. 9 predicts that CG fits very tightly within the binding pocket of $E R \alpha$.

\section{Discussion}

In this paper we characterize a novel derivative of genistein (G), 6-carboxymethyl genistein (CG), in terms of binding to ER $\alpha$ and $E R \beta$ and describe the transcriptional and agonistic and antagonistic effects of CG in vitro and in vivo in comparison to $\mathrm{G}$. In addition, computer modeling of the LBD-ER $\alpha-C G$ complex and the LBD-ER $\beta-C G$ complex is also used in order to correlate the structural models with the experimental findings.

The introduction of a carboxymethyl group to position 6 of $\mathrm{G}$ causes the derivative $\mathrm{CG}$ to bind selectively to $\mathrm{ER} \beta$, but minimally to ER $\alpha$. This difference may be due to the amino acid in $\operatorname{ER} \alpha$ and $\operatorname{ER} \beta$ interacting with the ligand. The contact amino acids are Ile at position 373 in $\operatorname{ER} \beta$ and most probably Met 421 in ER $\alpha$. It is known that Met 421 causes a decrease in the volume and polarity of the binding cavity (Pike et al. 1999) where the carboxymethyl group fits. It is suggested here that the minimal binding of CG to ER $\alpha$ (see Table 1) may be due to the presence of Met 421 in the LBD of ER $\alpha$.

Both compounds $G$ and $C G$ were capable of inducing transcription via an oestrogen receptor element in MCF-7 cells that possess endogeneous ER $\alpha$, and in 293 cells transfected with ER $\alpha$ or ER $\beta$. However, only CG and not $G$ was capable of displaying mixed agonist antagonist activity for ER $\alpha$ in MCF-7 and in 293 cells (Fig. 2A and B). No antagonism of CG could be detected in cells transfected with ER $\beta$ (Fig. 2). Under the same experimental conditions tamoxifen showed antagonistic effects only for ER $\alpha$ and not for ER $\beta$ (Fig. 2).

When the ability of $C G$ and $G$ to stimulate DNA synthesis was assessed in VSMCs, the cells were more sensitive to CG than $G$ by two orders of magnitude (Fig. 3, lower panel). Additionally CG lacked the inhibitory action on cell growth exerted by high concentrations of $\mathrm{G}$. Combination of a low dose of $\mathrm{G}(30 \mathrm{nM})$ with a low dose of $E_{2}$ had no effect on the response of $E_{2}$ with respect to DNA synthesis (Table 2). Moreover, CG at high dose blocked the inhibitory effect on proliferation seen at high concentrations of $E_{2}$ (Table 2). Interestingly both $G$ and CG at $30 \mathrm{nmol} / 1$ increased the CK response in VSMCs although the highest stimulation was seen at $300 \mathrm{nmol} / 1$ (Fig. 3, upper panel), and only CG at low and high doses attenuated the CK response in these cells in the presence of $E_{2}$ (Table 2). The SERM RAL inhibited the CK response to $\mathrm{E}_{2}, \mathrm{G}$ and $\mathrm{CG}$ at both low and high doses (Table 2). RAL inhibited DNA synthesis induced by CG at high dose and did not affect the stimulation or suppression of the DNA synthesis induced by $\mathrm{E}_{2}$ or CG (Table 2).

When the effects of $G$ and $C G$ were examined in E304 cells both compounds stimulated DNA synthesis and CK response in these cells (Fig. 4). However, the combination of $E_{2}$ with $G$ caused an augmentation of the response in both DNA synthesis and CK induction whereas the combination of $\mathrm{E}_{2}$ with $\mathrm{CG}$ caused an attenuation of proliferation and CK activity (Fig. 4). In these cells RAL inhibited both DNA synthesis and CK induced by either $\mathrm{E}_{2}$ or $\mathrm{G}$ or $\mathrm{CG}$ (Fig. 4).

In experiments using immature or ovariectomized female rats both $G$ and $E_{2}$ stimulated CK specific activity in all the tissues tested (epiphyseal cartilage, diaphyseal bone, pituitary, uterus, left ventricle of the heart and aorta) (Figs 5-7). Moreover, similar to RAL CG stimulated CK specific activities in all these tissues with the exception of the uterus (Figs 5-7). When rats were treated with a combination of $E_{2}(0.5 \mu \mathrm{g} / \mathrm{rat})$ plus $\mathrm{CG}(100 \mu \mathrm{g} / \mathrm{rat})$ or $\mathrm{E}_{2}(0.5 \mu \mathrm{g} / \mathrm{rat})$ plus RAL $(0.5 \mathrm{mg} / \mathrm{rat})$, the stimulatory response to $E_{2}$ was attenuated in all the rat tissues tested (Figs 5-7), thus indicating that CG acts like a SERM in these tissues. When the rats were treated with a combination of $E_{2}$ plus $G$, an increase in CK was observed only in the aorta and pituitary. Moreover, treatment of rats with RAL plus $G$ or RAL plus CG caused an inhibition of CK response in all tissues tested (Figs 5-7). Compared with RAL, CG is as effective at 5 to 10 times lower concentrations in blocking the $\mathrm{CK}$ response to $\mathrm{E}_{2}$ in rat tissues in vivo.

Pending crystallographic evidence of CG complexed to $\operatorname{ER} \alpha$ and to $\operatorname{ER} \beta$ limited computer modelling was performed in order to suggest an hypothesis on the anti-oestrogenic properties of CG. The modelling was performed in a very conservative way, choosing not to model protein fluctuations, but merely the orientation of 


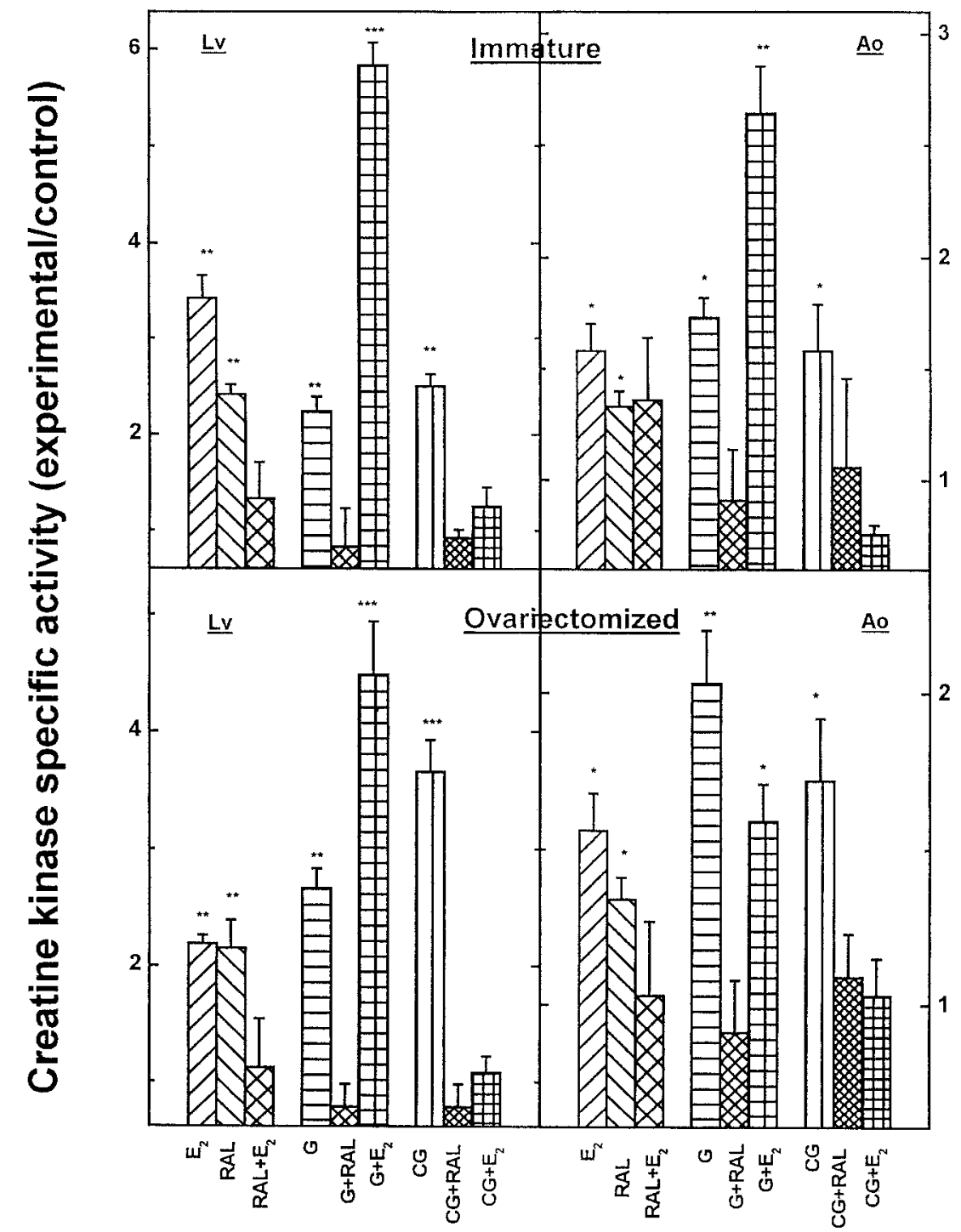

Figure 7 The effect of $E_{2}(5 \mu \mathrm{g}), \mathrm{G}(0.5 \mathrm{mg}), \mathrm{CG}(50 \mu \mathrm{g})$ and $\mathrm{RAL}(0.5 \mathrm{mg})$ alone or in the presence of RAL $(0.5 \mathrm{mg})$ or $\mathrm{E}_{2}(5 \mu \mathrm{g})$ on CK specific activity in the left ventricle of the heart (Lv) and the aorta (Ao) in immature (upper panel) or ovariectomized (lower panel) female rats. Results are means \pm S.E.M. of 5-15 assays from 2-3 experiments and are expressed as the ratio between the specific activity of CK in hormone-treated and control animals. ${ }^{*} P<0 \cdot 05,{ }^{* \star} P<0 \cdot 01,{ }^{* *} P<0 \cdot 001$.

the ligand in the binding cavity. Since the 3D structure of the LBD-ER $\beta-G$ complex has been determined (Pike et al. 1999), a carboxymethyl group at the 6 position of genistein was added manually. Energy minimization and docking were subsequently performed using the SYBYL modules. Figure 8 illustrates the LBD-ER $\beta-$ CG complex with the phenolic hydroxyl group at position 5 and the keto group at position 4 pointing towards the alpha face of the binding pocket. It is evident from the model that CG almost fits in the binding pocket. This may be due to the presence of Ile 373 which enables ER $\beta$ to accommodate more polar substituents at the distal end of the cavity.

So far, all the side chains of the anti-oestrogens (e.g. 4-OH tamoxifen, raloxifene) have been positioned through the $11 \beta$ channel (Pike et al. 1999). The carboxymethyl group in CG is not long enough to stick into the $11 \beta$ channel. Instead, in the simple model of LBDER $\alpha-C G$ through the beta face (Fig. 9) the carboxymethyl group at the 6-position of CG interacts with Leu 


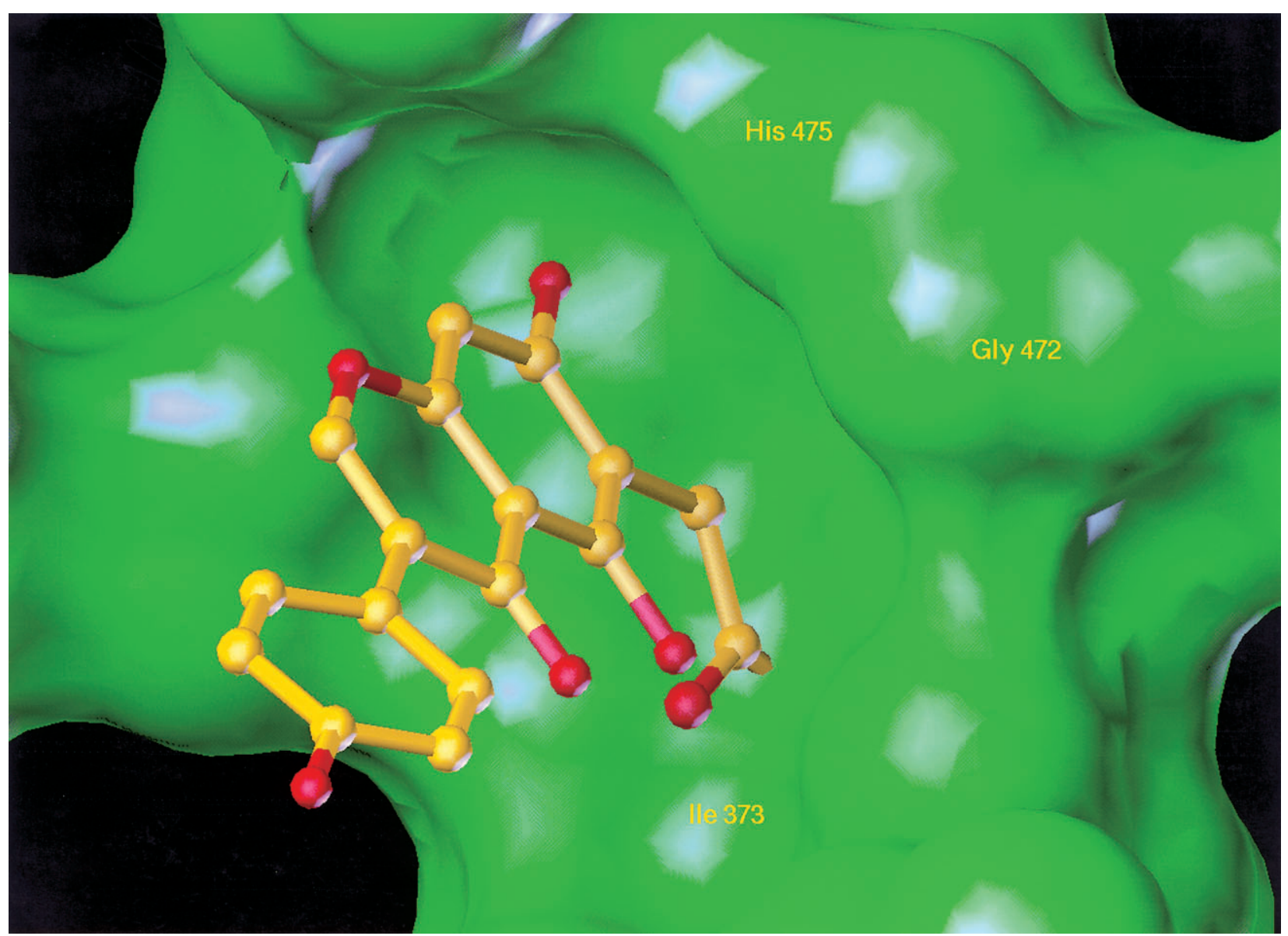

Figure 8 Docked 'model structure' obtained for CG bound to the ligand binding domain of ER $\beta$ through the alpha face. This model was rendered with SYBYL 6.7. Oxygen atoms are depicted red, the oestrogen receptor green and interacting amino acids yellow.

525, a key residue of Helix 11. It is known (Gangloff et al. 2001) that Leu 525 adjusts its position to compensate the ligand's different binding modes. In that same study (Gangloff et al. 2001) it has been shown that distruption of Helix 11 terminus results in lengthening of loop 11-12 and allows Helix 12 to reach the coactivator binding groove. Therefore, it can be hypothesized from the model that CG binds in ER $\alpha$ in the beta face and in this way CG disturbs the terminus of Helix 11, eliciting a conformational change in the orientation of Helix 12. This hypothesis is consistent with the generally accepted mechanism of 'antagonism' in ER, as reported by Gangloff et al. (2001), that steric hindrance inhibits the natural agonist conformation and favours an alternative position for Helix 12.

Given the correlation between the model structure of CG within the LBD of ER $\alpha$ and the observed antioestrogenic activities, the docked model of LBDER $\alpha-C G$ complex shown in Fig. 9 suggests a new mechanism for eliciting an anti-oestrogenic response.
In summary, introduction of a carboxymethyl group at the 6-position of genistein imparts anti-oestrogenic properties to CG, and causes $C G$ to act as a mixed antagonist both in vitro and in vivo. Since CG shows no oestrogenic activity in the uterus in terms of stimulation of CK activity, blocks the response of $E_{2}$ to $C K$ in the uterus and shows oestrogenic activity at low doses in the bone and vasculature, CG can be considered a novel SERM.

\section{Acknowledgements}

We are grateful to Dr H Thole for the generous gift of polyclonal anti-goat antibody raised against the carboxy terminal of the porcine ER $\alpha$ and to Dr B van der Burg for 3 xERE-TATA-Luc reporter, to Dr D McDonnell for the cDNA probes for ER $\alpha$ and ER $\beta$ and to Drs S Anzali, G Barnickel and F Rippmann for valuable discussions. The synthesis of 6-carboxymethyl genistein was in part supported by a USPHS NIEHS core grant P30ES06676. 


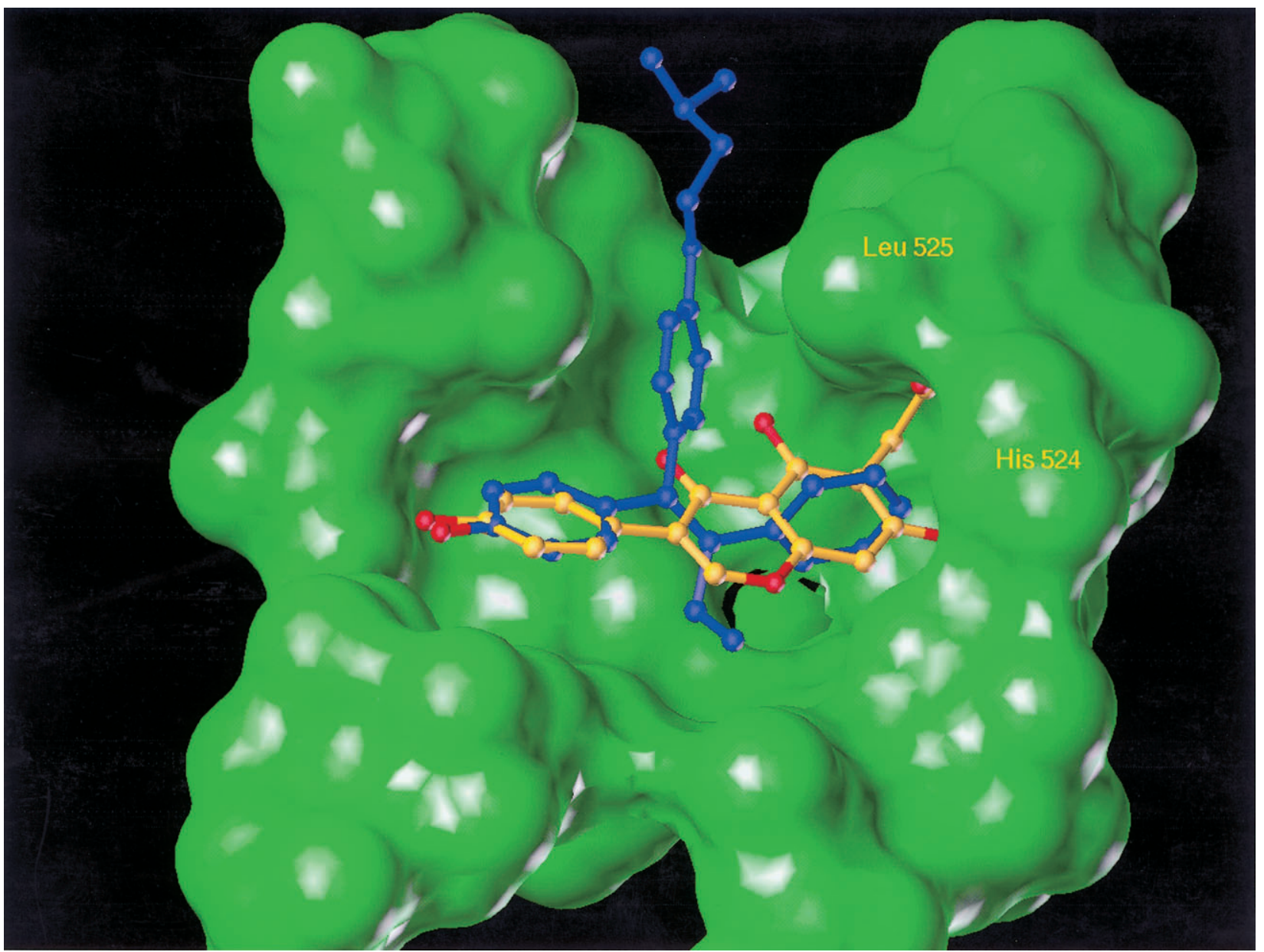

Figure 9 Docked 'model structure' obtained for CG bound to the ligand binding domain of ER $\alpha$ through the beta face. Note the 6-carboxymethyl of CG interacts with Leu 525 causing a severe backbone change at the end of Helix 11. For comparison purposes tamoxifen has been superimposed. The structures are coloured yellow for CG and blue for tamoxifen. Oxygen atoms are depicted red, the oestrogen receptor green and interacting amino acids yellow. This model was rendered with SYBYL 6·7.

\section{References}

Amir-Zaltsman Y, Mazor O, Gayer B, Scherz A, Salomon Y \& Kohen F 2000 Inhibitors of protein tyrosine phosphorylation: preliminary assessment of activity by time-resolved fluorescence. Luminescence 15 377-380.

Barnes S 1997 The chemopreventive properties of soy isoflavonoids in animal models of breast cancer. Breast Cancer Research and Treatment 46 169-179.

Barnes S, Sfakianos J, Coward L \& Kirk M 1996 Soy isoflavonoids and cancer prevention. Underlying biochemical and pharmacological issues. Advances in Experimental Medicine and Biology 401 87-100.

Barnes S, Boersma B, Patel R, Kirk M, Darley-Usmar VM, Kim H \& $\mathrm{Xu} \mathrm{J} 2000$ Isoflavonoids and chronic disease: mechanisms of action. Biofactors 12 209-215.

Brzozowski AM, Pike AC, Dauter Z, Hubbard RE, Bonn T, Engstrom O, Ohman L, Greene GL, Gustafsson JA \& Carlquist M 1997 Molecular basis of agonism and antagonism in the oestrogen receptor. Nature $389753-758$.
Egner U, Heinrich N, Ruff M, Gangloff M, Mueller-Fahrnow A \& Wurtz JM 2001 Different ligands - different receptor conformations: modeling of the hERalpha LBD in complex with agonists and antagonists. Medicinal Research Reviews 21 523-539.

Fiedor P, Kozerski L, Dobrowolski JC, Kawecki R, Biniecki K, Pachecka J, Rowinski W \& Mazurek AP 1998 Immunosuppressive effects of synthetic derivative of genistein on the survival of pancreatic islet allografts. Transplantation Proceedings 30537.

Gangloff M, Ruff M, Eiler S, Duclaud S, Wurtz JM \& Moras D 2001 Crystal structure of a mutant hERalpha ligand-binding domain reveals key structural features for the mechanism of partial agonism. Journal of Biological Chemistry 276 15059-15065.

Kohen F, Gayer B, Amir-Zaltsman Y, Ben-Hur H, Thomas E \& Lu LJ 1999 A nonisotopic enzyme-based immunoassay for assessing human exposure to genistein. Nutrition and Cancer 35 96-103.

Kuiper GG, Lemmen JG, Carlsson B, Corton JC, Safe SH, van der Saag PT, van der Burg B \& Gustafsson JA 1998 Interaction of 
estrogenic chemicals and phytoestrogens with estrogen receptor beta. Endocrinology 139 4252-4263.

Pike AC, Brzozowski AM, Hubbard RE, Bonn T, Thorsell AG, Engstrom O, Ljunggren J, Gustafsson JA \& Carlquist M 1999 Structure of the ligand-binding domain of oestrogen receptor beta in the presence of a partial agonist and a full antagonist. EMBO Journal 18 4608-4618.

Pike AC, Brzozowski AM, Walton J, Hubbard RE, Bonn T, Gustafsson JA \& Carlquist M 2000 Structural aspects of agonism and antagonism in the oestrogen receptor. Biochemical Society Transactions 28 396-400.

Pike AC, Brzozowski AM, Walton J, Hubbard RE, Thorsell AG, Li YL, Gustafsson JA \& Carlquist M 2001 Structural insights into the mode of action of a pure antiestrogen. Structure 9 145-153.

Setchell KD 2001 Soy isoflavones - benefits and risks from nature's selective estrogen receptor modulators (SERMs). Journal of the American College of Nutrition 20 354S-362S; discussion 381S-383S.
Sobolev V, Sorokine A, Prilusky J, Abola EE \& Edelman M 1999 Automated analysis of interatomic contacts in proteins. Bioinformatics 15 327-332.

Somjen D, Kohen F, Jaffe A, Amir-Zaltsman Y, Knoll E \& Stern N 1998 Effects of gonadal steroids and their antagonists on DNA synthesis in human vascular cells. Hypertension $\mathbf{3 2}$ 39-45.

Somjen D, Kohen F, Amir-Zaltsman Y, Knoll E \& Stern N 2000 Vitamin D analogs modulate the action of gonadal steroids in human vascular cells in vitro. American Journal of Hypertension 13 396-403.

Strasburger CJ \& Kohen F 1990 Two-site and competitive chemiluminescent immunoassays. Methods in Enzymology 184 481-496.

Received 6 December 2001

Accepted 21 February 2002 